\title{
Supportive Infusions in Integrative Breast and Gynecological Oncology - Report on Patients' Satisfaction and Self-reported Effects and Side Effects
}

\author{
Unterstützende Infusionen in der integrativen Onkologie \\ bei Brustkrebs und gynäkologischen Krebserkrankungen - \\ Bericht über die Zufriedenheit der Patientinnen sowie über \\ selbstberichtete Wirkungen und Nebenwirkungen
}

\section{(C) $(9) \Theta$}

Authors

Carolin C. Hack ${ }^{1}$, Sophia Antoniadis ${ }^{1}$, Matthias W. Beckmann ${ }^{1}$, Anna Lisa Brandl ${ }^{1}$, Peter A. Fasching ${ }^{1}$, Janina Hackl ${ }^{1}$, Hanna Langemann ${ }^{1}$, Stock Katja ${ }^{2}$, Natalie Weber ${ }^{1}$, Anna-Katharin Theuser ${ }^{1}$

\section{Affiliations}

1 Department of Gynecology and Obstetrics, Erlangen University Hospital, Comprehensive Cancer Center

Erlangen - European Metropolitan Area Nuremberg (CCC ER-EMN), Friedrich Alexander University of ErlangenNuremberg, Erlangen, Germany

2 Department of Pharmacy, Erlangen University Hospital, Erlangen, Germany

Key words

cancer, gynecological oncology, breast cancer, vitamins, infusion, dietary supplements, micronutrients, integrative medicine, complementary and alternative medicine

\section{Schlüsselwörter}

Krebs, gynäkologische Onkologie, Brustkrebs, Vitamine, Infusion, Nahrungsergänzungsmittel, Mikronährstoffe, integrative Medizin, komplementäre und alternative Medizin

$\begin{array}{lr}\text { received } & 30.7 .2018 \\ \text { revised } & 14.9 .2018 \\ \text { accepted } & 5.10 .2018\end{array}$

Bibliography

DOI https://doi.org/10.1055/a-0754-2923

Geburtsh Frauenheilk 2018; 78: 1129-1137 @ Georg Thieme

Verlag KG Stuttgart · New York I ISSN 0016-5751
Correspondence

Carolin C. Hack, MD

Department of Gynecology and Obstetrics, Erlangen University Hospital, Comprehensive Cancer Center Erlangen European Metropolitan Area Nuremberg (CCC ER-EMN), Friedrich Alexander University of Erlangen-Nuremberg Universitätsstraße 21-23, 91054 Erlangen, Germany carolin.hack@uk-erlangen.de

E

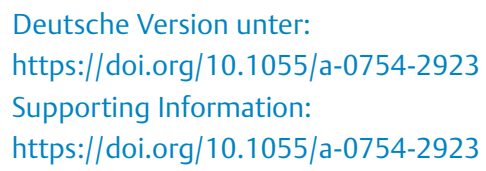

\section{ABSTRACT}

Background During cancer therapy, many patients suffer from malnutrition or vitamin deficiency. Treatment for nutrition-related deficiencies should therefore include nutritional therapy and possibly oral or intravenous substitution of micronutrients. Little information exists on multinutrient infusion therapies. The aim of this study was to develop standardized infusion protocols for integrative medicine infusions with micronutrients (IMed infusions) and to report on side effects of the treatment and patients' satisfaction with it.

Methods For the IMed consultancy service, four special formulas for intravenous use were developed in cooperation with the pharmacy at Erlangen University Hospital. A retrospective cross-sectional study was conducted between October 2015 and January 2018 in which 45 patients with gynecological or breast cancer (BC) and IMed infusion therapy were included. Follow-up data were obtained from 20 patients using a standardized questionnaire on IMed infusions.

Results A total of 280 IMed infusions were administered in the study period. The majority of the patients received an 
IMed regeneration infusion (78\%). The majority of the patients had BC and were receiving chemotherapy. Most patients reported a high or very high level of satisfaction with the organization (60\%), general treatment (65\%) and counseling (85\%). Subjective improvement in their disease-related and therapy-induced symptoms, such as fatigue, polyneuropathy and physical efficiency, was reported by $70 \%$ of the patients, while $75 \%$ reported a subjective increase in quality of life. Side effects were rare and minor.

Conclusions Therapy with IMed infusions in women with BC or gynecological cancer requires the same standards set for drug therapy. Although vitamins represent dietary supplements, appropriate assessment of the patient's medical history is needed and patients must receive appropriate information. For this purpose, standardized processes, as in the context of an IMed consultancy service, are helpful.

\section{ZUSAMMENFASSUNG}

Hintergrund Während einer Krebstherapie leiden viele Patienten an Mangelernährung oder Vitaminmangel. Die Behandlung nährstoffbezogener Mangelzustände sollte daher eine Ernährungstherapie und gegebenenfalls auch eine orale oder intravenöse Substitution von Mikronährstoffen beinhalten. Über Infusionstherapien mit mehreren Nährstoffen liegen nur wenige Informationen vor. Das Ziel dieser Studie bestand in der Entwicklung standardisierter Infusionsprotokolle für die Infusion von Mikronährstoffen im Rahmen der integrativen Medizin (IMed-Infusionen) und der Beschreibung von Nebenwirkungen der Behandlung und der Therapiezufriedenheit der Patientinnen.

Methoden Für die IMed-Sprechstunde wurden in Zusammenarbeit mit der Apotheke des Universitätsklinikums Erlan- gen 4 spezielle Formulierungen für die intravenöse Anwendung entwickelt. Zwischen Oktober 2015 und Januar 2018 wurde eine retrospektive Querschnittsstudie durchgeführt, in der 45 Patientinnen mit gynäkologischen Krebserkrankungen oder Brustkrebs (BK) unter IMed-Infusionstherapie aufgenommen wurden. Von 20 Patientinnen wurden mithilfe eines standardisierten Fragebogens zu IMed-Infusionen Nachbeobachtungsdaten erhoben.

Ergebnisse Während des Studienzeitraums wurden insgesamt 280 IMed-Infusionen verabreicht. Die meisten Patientinnen haben IMed-Regenerationsinfusionen erhalten (78\%). Die Patientinnen litten in der Mehrzahl der Fälle an BK und wurden mit Chemotherapie behandelt. Die meisten Patientinnen gaben ein hohes oder sehr hohes Maß an Zufriedenheit mit der Organisation (60\%), der allgemeinen Behandlung (65\%) und der Beratung (85\%) an. Über eine subjektive Besserung von krankheits- oder therapiebedingten Symptomen wie Fatigue, Polyneuropathie und Einschränkung der körperlichen Leistungsfähigkeit berichteten 70\% der Patientinnen, während 75\% eine subjektive Steigerung ihrer Lebensqualität angaben. Nebenwirkungen traten nur selten auf und waren leichter Natur.

Schlussfolgerungen Die Therapie mit IMed-Infusionen bei Frauen mit BK oder gynäkologischen Krebserkrankungen muss denselben Standards genügen wie Arzneimitteltherapien. Obwohl es sich bei Vitaminen um Nahrungsergänzungsmittel handelt, sind eine gründliche Erhebung der Anamnese sowie eine angemessene Aufklärung der Patientinnen unerlässlich. Hierfür haben sich standardisierte Vorgehensweisen, wie im Rahmen der IMed-Sprechstunde der Fall, als hilfreich erwiesen.

\section{Introduction}

Integrative medicine is a holistic approach to treatment in which the aim is to combine conventional, evidence-based medicine with experience-based complementary therapies, providing a combined medical treatment procedure [1 - 3].

Especially amogst cancer patients use of integrative medicine is popular with $38-60 \%$ of the patients in Europe, USA and Australia reporting use [4]. Patients with breast cancer or gynecological cancers in particular look for holistic treatment approaches [8, 9], and the uptake of CAM in this group is reported to be as high as $73.3 \%$, depending on the site and stage of the disease [5-7]. A survey among doctors working in the field of gynecological cancer in Germany showed that the most common recommendations offered in connection with integrative medicine, next to exercise, are nutritional counseling and therapy with dietary supplements such as micronutrients and vitamins [11]. The high level of interest among cancer patients and the physicians treating them in nutritional therapy and micronutrient supplementation can be explained on the basis of studies showing that, during administration of chemotherapy, plasma concentrations of antioxidants such as vitamin $C$ and vitamin $E$ are reduced, while at the same time micronutrient excretion is increased [12]. In addition, patients often suffer from micronutrient insufficiency due to common side effects of anti-cancer treatment. Nausea and vomiting or mucositis often make it impossible for patients to ingest sufficient amounts of micronutrients and vitamins. At the same time, many patients suffer from diarrhea as a side effect of chemotherapy. Cancer patients often even develop a state of malnutrition as a result of decreased nutrient intake and increased nutrient excretion [13]. Nutritional therapy in our integrative medicine consultancy service thus usually includes oral and intravenous micronutrient formulations as a combined treatment concept.

It has also been hypothesized that integrative therapy with micronutrients and vitamins can reduce the untoward side effects of conventional cancer therapy and increase patients' quality of life. In a phase I dose-finding clinical trial assessing vitamin $C$ infusion in cancer patients with concomitant chemotherapy, quality of life remained stable at a dosage of $0.6 \mathrm{~g} / \mathrm{kg}$, while physical function deteriorated in patients who received vitamin $C$ at lower doses [14]. Further clinical trials and observational studies indicated that the side effects of conventional chemotherapy can be reduced by vitamin C treatment, while quality of life improved; however, no benefits in relation to tumor response or survival were estab- 
lished, and overall the value of vitamin $C$ infusions in cancer therapy cannot at present be proven or disproved $[15,16]$. Little information is available on other multinutrient infusion therapies. Myers' Cocktail, developed by Dr. John Myers, is a mixture of multivitamins including ascorbic acid, pyridoxine hydrochloride, dexpanthenol, hydroxycobalamin, thiamine hydrochloride, and minerals such as magnesium, calcium, and other trace minerals. The original formula has often been modified. Patients receiving Myers' Cocktail have reported an increased feeling of energy or well-being and less fatigue, probably as a result of improved cellular energy metabolism $[17,18]$.

To meet the demands a consultancy service for integrative medicine was established in 2014 in the Department of Gynecology and Obstetrics at Erlangen University Hospital. The consultancy service follows a standardized procedure for assessing patients' medical history and carrying out the clinical examination, as well as for the development of individualized integrative treatment plans. Patients are treated by gynecologic oncologists who also have special training in naturopathy and complementary medicine. This approach makes it possible to offer patients highquality standards of care, and it is ensured that all complementary treatments are selected in coordination with conventional treatment [10].

The aim of the present study was to develop standardized infusion protocols for vitamin and micronutrient infusions to be included in the portfolio of the integrative medicine consultancy service. In this context, patients' satisfaction with treatment with integrative medicine infusions (IMed infusions) as well as the selfreported effects and side effects of IMed infusions were evaluated.

\section{Methods}

\section{Development of IMed infusions}

Four special formulas for intravenous use were developed for the integrative medicine consultancy service in collaboration with the local pharmacy at Erlangen University Hospital. The formulas were developed in accordance with good manufacturing practice, ensuring a very high level of product quality and safety. The integrative medicine infusion solutions (IMed infusions) were designed to contain an effective and safe dose of vitamins as well as micronutrients. The multinutrient infusions were freshly prepared in the pharmacy on the day of administration, in standardized conditions. Special features such as the rapid decay of vitamins under the influence of heat and light were taken into account (cooling of the infusion bag, fast delivery and application, short storage time, light-protection pouch). All patients received detailed information regarding the composition of the formulars and possible associated risks before the first infusion and had to provide written consent for treatment with IMed infusions. The composition of the individual formulas is summarized in $>$ Table 1 . The administration of the IMed infusions takes place in course of the integrative medicine consultancy service and occurs under medical supervision.

In addition to the specially developed formulas, a prefabricated product, Medivitan ${ }^{\circledR}$, is also used in the integrative medicine consultancy service. All IMed infusions are offered to patients as indi- vidual health services. The recommendation of a specific IMed infusion is based on symptoms and complaints stated by patients in the integrative medicine consultancy service as well as their individual treatment goals. Regarding safety, the medical history and current cancer treatment are also taken into consideration. Laboratory values and nutritional state are taken in account whenever available.

\section{Patient survey}

All patients provided written informed consent. The study protocol was in accordance with the Declaration of Helsinki and was approved by the local ethics review committee. This retrospective cross-sectional survey was conducted at the integrative medicines consultancy service in the Department of Gynecology and Obstetrics at Erlangen University Hospital. A standardized questionnaire on IMed infusions was developed and validated in a group of 21 oncological patients receiving infusion therapy with zoledronic acid at the Department of Gynecology and Obstetrics at Erlangen University Hospital between October 9 and October 13,2017 . These patients received the original questionnaire along with an evaluation sheet including items on "time required to complete the questionnaire", as well as "complexity", "comprehensibility", and whether patients "liked the questionnaire" or had suggestions for improvement. The initial questionnaire on IMed infusions was revised after the validation phase before being used in the final survey.

The cross-sectional survey included patients who received IMed infusions in the integrative medicine consultancy service between October 2015 and January 2018 - a total of 56 patients. Two patients were excluded from the analysis as they had other tumor entities, and four patients died before the follow-up. A further two patients had to be excluded because detailed consultation and medical history-taking on integrative medicine did not take place. In three patients, the follow-up period was too short, and the survey of IMed infusions had not yet been carried out. The analysis was conducted with complete datasets for 45 patients with gynecological or breast cancer. Patients were eligible for inclusion if they were suffering from either breast cancer or gynecological cancer, such as carcinoma of the ovaries, cervix, endometrium, or vulva.

The patients' clinical records were used to collect information on patient and tumor characteristics. The patients' characteristics and the applications of multinutrient infusions were evaluated for all patients. During the follow-up survey, patients completed the validated, standardized questionnaire on IMed infusions. Only patients who answered the follow-up questionnaire within 4 months after the last multinutrient infusion were included in the final analysis. The questionnaire included eleven items with questions on patients' overall satisfaction with treatment and counseling regarding IMed infusions, subjective assessment of tolerance, and subjective assessment of improvements in symptoms and quality of life (Appendices 1 and 2). Follow-up data were obtained from 20 patients within 4 months. For the other 25 patients, the follow-up period since the last infusion was too long.

Patients' satisfaction with IMed infusions was measured using a six-point scale with 1 being the best grade ("very satisfied") and 6 being the worst grade ("very dissatisfied"). Questions on toler- 
- Table 1 Formulas used in the IMed infusions.

\begin{tabular}{|c|c|c|c|c|}
\hline & IMed immune infusion & IMed regeneration infusion & IMed vital infusion & IMed cell protection infusion \\
\hline Formula & $\begin{array}{l}\text {. } 15 \mathrm{~g} \text { ascorbic acid } \\
\text {. } 218.7 \text { mg magnesium } \\
\text { (as magnesium aspartate) } \\
\text {. } 250 \mathrm{~mL} \text { Ringer's lactate } \\
\text { solution }\end{array}$ & $\begin{array}{l}\text { - } 7.5 \mathrm{~g} \text { ascorbic acid } \\
\text { - Thiamine hydrochloride } \\
200 \mathrm{mg} \\
\text { - Pyridoxine hydrochloride } \\
\text { cyanocobalamin } 1 \mathrm{mg} \\
\text { - Calcium } 92.09 \mathrm{mg} \\
\text { (as calcium gluconate) } \\
\text { - } 218.7 \mathrm{mg} \text { magnesium } \\
\text { (as magnesium aspartate) } \\
\text { - } 250 \mathrm{~mL} \text { sodium chloride } \\
\text { solution } 0.9 \%\end{array}$ & $\begin{array}{l}\text { - } 200 \mathrm{mg} \text { procaine hydro- } \\
\text { chloride } \\
\text { - } 500 \mathrm{~mL} \text { sodium chloride } \\
\text { solution } 0.9 \% \\
\text { - } \text { Dose escalation is possible } \\
\text { according to the following } \\
\text { scheme: } \\
\text { - Infusion } 1: 100 \text { mg procaine } \\
+20 \mathrm{~mL} \text { sodium hydrogen } \\
\text { carbonate solution } 8.4 \% \\
\text { - Infusion } 2: 200 \mathrm{mg} \text { procaine } \\
\text { + } 30 \mathrm{~mL} \text { sodium hydrogen } \\
\text { carbonate solution } 8.4 \% \\
\text { - Infusion } 3: 300 \text { mg procaine } \\
+40 \mathrm{~mL} \text { sodium hydrogen } \\
\text { carbonate solution } 8.4 \% \\
\text { - Infusion } 4: 400 \mathrm{mg} \text { procaine } \\
\text { + } 50 \mathrm{~mL} \text { sodium hydrogen } \\
\text { carbonate solution } 8.4 \% \\
\text { - Infusion } 5: 10: 500 \text { mg } \\
\text { procaine + } 60 \mathrm{~mL} \text { sodium } \\
\text { hydrogen carbonate solu- } \\
\text { tion } 8.4 \%\end{array}$ & $\begin{array}{l}1 \text { vial Ubiquinone } \text { Heel}^{\circledR} \\
\text { (homeopathic drug) } \\
218.7 \text { mg magnesium } \\
\text { (as magnesium aspartate) } \\
250 \mathrm{~mL} \text { sodium chloride } \\
\text { solution } 0.9 \%\end{array}$ \\
\hline Administration & $\begin{array}{l}\text { - Administer } 0.5-1.0 \mathrm{~g} \\
\text { of calcium about } 30 \mathrm{~min} \\
\text { prior to infusion } \\
\text { - Infuse over a time period } \\
\text { of } 30 \text { min }\end{array}$ & $\begin{array}{l}\text { - Infuse over a time period } \\
\text { of } 60 \mathrm{~min}\end{array}$ & $\begin{array}{l}\text { - Infuse over a time period } \\
\text { of } 40 \mathrm{~min}\end{array}$ & $\begin{array}{l}\text { - Administer } 0.5-1.0 \mathrm{~g} \\
\text { of calcium about } 30 \mathrm{~min} \\
\text { prior to infusion } \\
\text { - Infuse over a time period } \\
\text { of } 30 \mathrm{~min}\end{array}$ \\
\hline $\begin{array}{l}\text { Recommended } \\
\text { dose }\end{array}$ & $\begin{array}{l}\text { - One infusion per week } \\
\text { for a period of } 10 \text { weeks } \\
\text { - Administer no less than } \\
3 \text { days after administration } \\
\text { of chemotherapy }\end{array}$ & $\begin{array}{l}\text { - One infusion per week } \\
\text { for a period of } 10 \text { weeks }\end{array}$ & $\begin{array}{l}\text { - One infusion per week } \\
\text { for a period of } 10 \text { weeks }\end{array}$ & $\begin{array}{l}\text { - One infusion per week } \\
\text { for a period of } 10 \text { weeks } \\
\text { - Administer no less than } \\
3 \text { days after administration } \\
\text { of chemotherapy }\end{array}$ \\
\hline Effects & $\begin{array}{l}\text { - Stimulating } \\
\text { - Anti-oxidative } \\
\text { - Anti-inflammatory } \\
\text { - Immune modulating } \\
\text { - Increases wound healing } \\
\text { - Improves overall balance }\end{array}$ & $\begin{array}{l}\text { - Stimulating } \\
\text { - Anti-oxidative } \\
\text { - Anti-inflammatory } \\
\text { - Immune modulating } \\
\text { - Neuroprotective } \\
\text { - Regenerating }\end{array}$ & $\begin{array}{l}\text { " Stimulating } \\
\text { " Anti-inflammatory } \\
\text { - Anxiolytic } \\
\text { - Increases blood flow } \\
\text { - Deacidifying } \\
\text { - Relaxing } \\
\text { - Vitalizing }\end{array}$ & $\begin{array}{l}\text { - Stimulating } \\
\text { - Anti-oxidative } \\
\text { - Improves overall balance } \\
\text { - Decreases cholesterol level } \\
\text { - Cardioprotective } \\
\text { - Protects cells }\end{array}$ \\
\hline Precautions & $\begin{array}{l}\text { - Consider regular assess- } \\
\text { ment of renal function } \\
\text { - Do not use in patients with } \\
\text { renal insufficiency, patients } \\
\text { with oxalate urolithiasis, or } \\
\text { patients with iron storage } \\
\text { deficiencies }\end{array}$ & $\begin{array}{l}\text { - Monitor cardiac function } \\
\text { carefully in elderly patients } \\
\text { or patients with impaired } \\
\text { cardiac function } \\
\text { - Do not use in patients re- } \\
\text { ceiving therapy with digi- } \\
\text { toxin or digoxin, patients } \\
\text { with renal insufficiency, } \\
\text { patients with oxalate uro- } \\
\text { lithiasis or patients with iron } \\
\text { storage deficiencies }\end{array}$ & $\begin{array}{l}\text { - Monitor patient carefully } \\
\text { and ensure good hydration } \\
\text { state and stable cardio- } \\
\text { vascular system } \\
\text { - Test for procaine intoler- } \\
\text { ance before administering } \\
\text { the infusion } \\
\text { - Do not use in patients with } \\
\text { procaine intolerance }\end{array}$ & $\begin{array}{l}\text { - Consider regular assess- } \\
\text { ment of renal function } \\
\text { - Do not use in patients with } \\
\text { renal insufficiency, patients } \\
\text { with oxalate urolithiasis, or } \\
\text { patients with iron storage } \\
\text { deficiencies }\end{array}$ \\
\hline
\end{tabular}

ance of IMed infusions or improvement of symptoms or quality of life were assessed using a three-point scale or simple "yes" and "no" answers. "I don't know" responses were not included in the final analysis. All patients were asked if they had experienced any side effects during treatment with IMed infusions. If this question was answered with "yes," the patients were asked to specify what side effects they experienced.
Statistical evaluation was performed using descriptive analysis, including the calculation of absolute numbers and percentages. Analysis of patient satisfaction was conducted by calculating medians and ranges. Factors influencing improvements in quality of life and improvements in symptoms were assessed. All calculations were done using the statistics program IBM SPSS, version 
- Table 2 Characteristics of patients and tumors, showing means and standard deviation (SD) for continuous characteristics and frequencies and percentages for categorical characteristics $(n=45)$.

\begin{tabular}{|c|c|c|}
\hline Characteristics & Mean or $\mathbf{n}$ & SD or $\%$ \\
\hline Age (years) & 51.5 & \pm 10.4 \\
\hline Body mass index $\left(\mathrm{kg} / \mathrm{m}^{2}\right)$ & 25.3 & \pm 4.5 \\
\hline \multicolumn{3}{|l|}{ Cancer type } \\
\hline - Breast & 36 & 80.0 \\
\hline - Ovary & 4 & 8.9 \\
\hline - Endometrium & 3 & 6.7 \\
\hline - Cervix & 1 & 2.2 \\
\hline - Chorion & 1 & 2.2 \\
\hline - Vagina/vulva & 0 & 0 \\
\hline \multicolumn{3}{|l|}{ Therapy situation } \\
\hline - Neoadjuvant & 15 & 33.3 \\
\hline - Adjuvant & 13 & 28.9 \\
\hline - Aftercare & 9 & 20.0 \\
\hline - Palliative & 8 & 17.8 \\
\hline \multicolumn{3}{|c|}{ Cancer treatment during infusions (multiple choices possible) } \\
\hline Chemotherapy & 30 & 66.6 \\
\hline - Carboplatin + paclitaxel & 13 & 28.9 \\
\hline $\begin{array}{l}\text { - Epirubicin/cyclophosphamide + } \\
\text { paclitaxel }\end{array}$ & 9 & 20.0 \\
\hline $\begin{array}{l}\text { - Carboplatin + paclitaxel + } \\
\text { epirubicin/cyclophosphamide }\end{array}$ & 2 & 4.4 \\
\hline - Other & 6 & 13.3 \\
\hline $\begin{array}{l}\text { Targeted therapy/angiogenesis } \\
\text { inhibitor }\end{array}$ & 6 & 13.3 \\
\hline - Pertuzumab + trastuzumab & 4 & 8.9 \\
\hline - Bevacizumab & 2 & 4.4 \\
\hline Endocrine therapy & 11 & 24.5 \\
\hline - Letrozole & 7 & 15.6 \\
\hline - Tamoxifen & 3 & 6.7 \\
\hline - Anastrozole & 1 & 2.2 \\
\hline Bisphosphonates & 7 & 15.6 \\
\hline - Zoledronate & 7 & 15.6 \\
\hline
\end{tabular}

21 (IBM Corporation, Armonk, New York, USA). Missing data were excluded from the analysis.

\section{Results}

\section{Characteristics of patients and tumors}

The analysis was conducted with complete datasets for 45 patients with gynecological or breast cancer. The patients' average age was $51.5( \pm 10.4)$ years, and their average body mass index was $25.3( \pm 4.5)$. The majority of the patients had breast cancer ( $n=36 ; 80 \%) ; 8.9 \%$ of the patients had ovarian cancer $(n=4)$; $6.7 \%$ had endometrial cancer $(n=3)$; and $2.2 \%$ of the patients were suffering from cervical cancer or chorionic cancer (each
- Table 3 IMed infusion characteristics, showing medians and ranges for continuous characteristics and frequencies and percentages for categorical characteristics ( $n=45$ patients).

\begin{tabular}{|c|c|c|c|c|}
\hline Infusion characteristics & $\mathbf{n}$ & $\%$ & Median & Range \\
\hline Number of total applications & 280 & 100.0 & & \\
\hline - IMed regeneration infusion & 165 & 58.9 & & \\
\hline - IMed immune infusion & 87 & 31.1 & & \\
\hline $\begin{array}{l}\text { - IMed cell protection } \\
\text { infusion }\end{array}$ & 19 & 6.8 & & \\
\hline - IMed vital infusion & 7 & 2.5 & & \\
\hline - Medivitan ${ }^{\circledR}$ & 2 & 0.7 & & \\
\hline Number of patients with: & 45 & 100.0 & & \\
\hline - IMed regeneration infusion & 35 & 77.8 & & \\
\hline - IMed immune infusion & 18 & 40.0 & & \\
\hline $\begin{array}{l}\text { - IMed cell protection } \\
\text { infusion }\end{array}$ & 8 & 17.8 & & \\
\hline - IMed vital infusion & 4 & 8.9 & & \\
\hline - Medivitan ${ }^{\circledR}$ & 2 & 4.5 & & \\
\hline Number of patients with: & 45 & 100.0 & & \\
\hline - Infusion therapy completed & 33 & 73.3 & & \\
\hline - Infusion therapy ongoing & 12 & 26.7 & & \\
\hline \multicolumn{5}{|l|}{ Number of infusions/patient: } \\
\hline - IMed regeneration infusion & & & 4 & $1-16$ \\
\hline - IMed immune infusion & & & 2 & $1-18$ \\
\hline $\begin{array}{l}\text { - IMed cell protection } \\
\text { infusion }\end{array}$ & & & 2.5 & $1-5$ \\
\hline - IMed vital infusion & & & 1.5 & $1-3$ \\
\hline - Medivitan ${ }^{\circledR}$ & & & 1 & 1 \\
\hline
\end{tabular}

$\mathrm{n}=1$ ). The treatment situation was neoadjuvant in $33.3 \%$ $(n=15)$, adjuvant in $28.9 \%(n=13)$, and palliative in $17.8 \%$ $(n=8)$. Twenty percent of the patients $(n=9)$ were in follow-up care. In all, $66.7 \%$ of the patients were receiving chemotherapy as conventional medicine parallel to the IMed infusions, $24.5 \%$ were receiving endocrine therapy, $13.3 \%$ were receiving targeted therapy/angiogenesis inhibitors, and $15.6 \%$ were receiving bisphosphonates. The characteristics of the patients and tumors are listed in $>$ Table 2.

\section{Infusion characteristics}

A total of 280 multinutrient infusions were administered during the study period. The IMed regeneration infusion was used most frequently, with 165 applications, followed by the IMed immune infusion with 87 applications and the IMed cell protection infusion with 19 applications. Thus, $77.8 \%$ of the patients received IMed regeneration infusions. The IMed immune infusion was recommended to $40 \%$ of the patients, and the IMed cell protection infusion to $17.8 \%$. The IMed infusion therapy plan has been completed by $73.3 \%$ of the patients, and $26.7 \%$ are still receiving IMed infusion therapy. Depending on the IMed infusion, up to four infusions were administered per patient on average. The detailed infusion characteristics are shown in $>$ Table 3. 


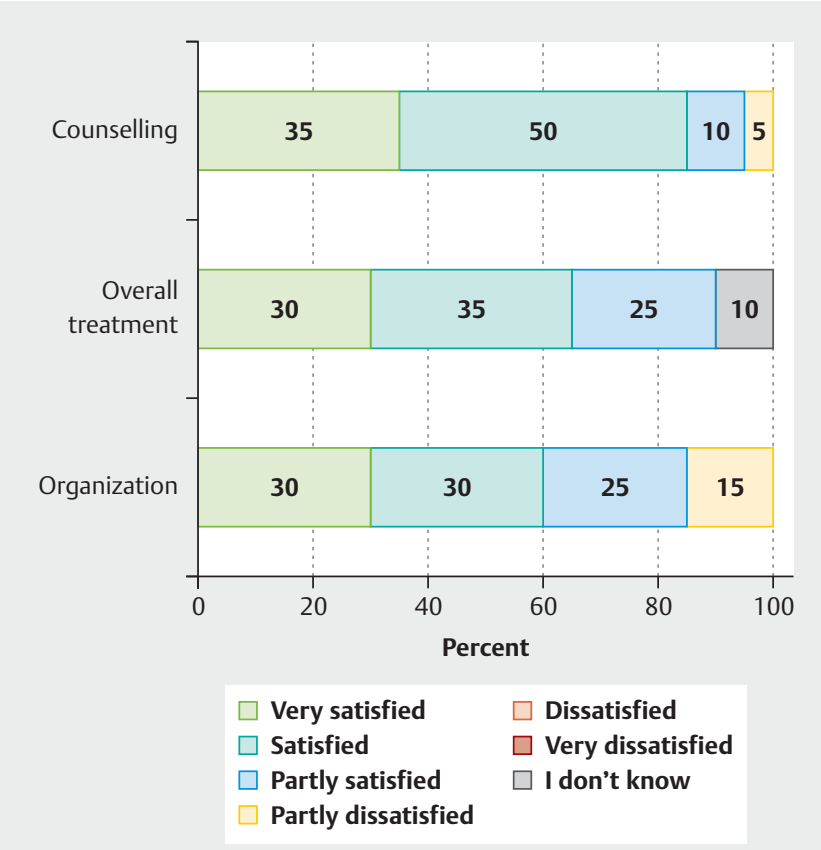

- Fig. 1 Patient's overall satisfaction with IMed infusions regarding counselling and organization $(n=20)$.

\section{Follow-up survey}

A follow-up survey was conducted in 20 patients with 104 multinutrient infusions. When asked about their satisfaction with the organization of the service, $60 \%$ said they were satisfied or very satisfied. The general treatment and counseling were also assessed very well, with good satisfaction rates of 65 and $85 \%$ ( $\triangleright$ Fig. 1). Patients' assessment of the side effects of IMed infusions was satisfactory in $55 \%$ and partly satisfactory in $30 \%$ of the patients. Seventy-five percent of the patients reported experiencing at least a partial improvement in quality of life ( $\bullet$ Fig. 2 ).

With regard to the retrospectively assessed side effects of multinutrient infusions, only mild adverse events occurred overall ( $\triangleright$ Table 4). The most common side effects were gastrointestinal complaints, headache, and exanthema (1.9\% of 104 applications). Even rarer side effects included nausea, fatigue syndrome, globus pharyngitis, cough, circulation problems, edema, and erroneously high blood glucose (1.0\% of 104 applications).

Seventy percent of the patients reported subjective improvement in their disease-related and therapy-induced symptoms. The frequencies of the improved symptoms are shown in $>$ Table 5. In addition, the evaluation showed that a total of $70 \%$ of the patients would certainly recommend the IMed infusions to others.

\section{Discussion}

The majority of the patients included in this study who were treated with IMed infusions were suffering from breast cancer and receiving ongoing chemotherapy. In clinical practice, the IMed regeneration infusion, the IMed immune infusion, and the IMed cell protection infusion were the most commonly used infusions. The

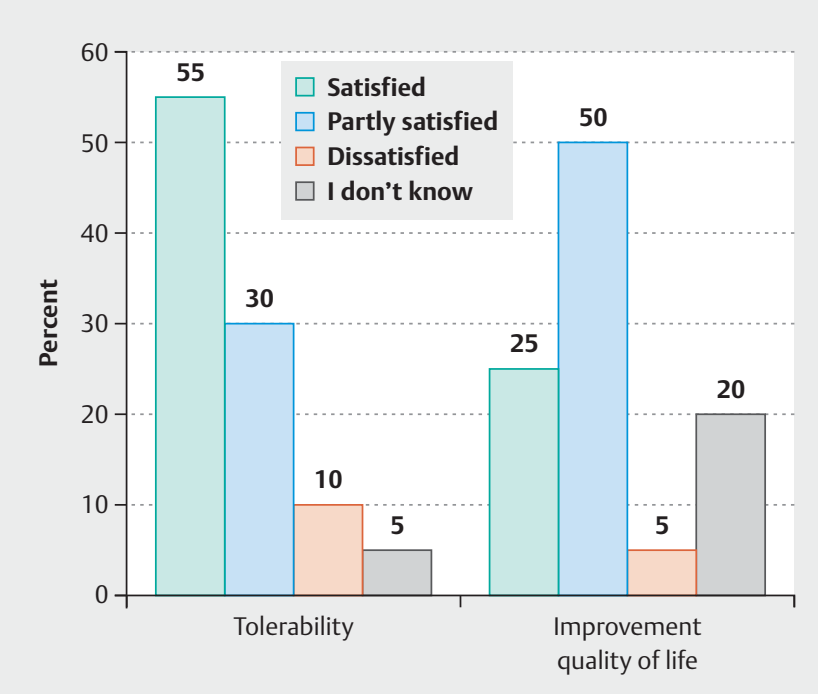

- Fig. 2 Patient's satisfaction with IMed infusions regarding tolerability and self-reported improvment of quality of life $(n=20)$.

- Table 4 Side effects associated with the multinutrient infusions ( $n=104$ applications in 20 patients). Categories of frequency: $>10 \%$, very often; $1-10 \%$, often; $0.1-1.0 \%$, sporadic; $0.01-0.1 \%$, rare; $<0.01 \%$ : very rare.

\begin{tabular}{|l|l|l|}
\hline Side effect & $\mathbf{n}$ & $\%$ \\
\hline Gastrointestinal symptoms & 2 & 1.9 \\
\hline Exanthema & 2 & 1.9 \\
\hline Headache & 2 & 1.9 \\
\hline Nausea & 1 & 1.0 \\
\hline Fatigue syndrome/tiredness/exhaustion & 1 & 1.0 \\
\hline Erroneously high blood glucose & 1 & 1.0 \\
\hline Globus pharyngis & 1 & 1.0 \\
\hline Cough & 1 & 1.0 \\
\hline Circulation problems & 1 & 1.0 \\
\hline Edema & 1 & 1.0 \\
\hline
\end{tabular}

- Table 5 Subjective improvement in disease-related and therapyinduced symptoms $(n=20)$; multiple answers were possible.

\begin{tabular}{|l|l|l|}
\hline Symptom & $\mathbf{n}$ & $\%$ \\
\hline Fatigue syndrome/tiredness/exhaustion & 7 & 35 \\
\hline Polyneuropathy & 4 & 20 \\
\hline Physical efficiency & 3 & 15 \\
\hline Nausea/emesis & 2 & 10 \\
\hline General condition & 2 & 10 \\
\hline Skin and mucosa status & 2 & 10 \\
\hline Lassitude & 1 & 5 \\
\hline
\end{tabular}


majority of the patients experienced subjective improvement in their symptoms, with a minor side effect profile.

It is well known that breast cancer patients show the greatest degree of commitment and initiative among all cancer patients, and that they frequently make use of integrative therapies $[4,6$, $19,20]$.

If the multinutrient infusion approach is offered, it should be done in standardized conditions and in accordance with a standardized protocol. This is reflected by the high satisfaction with the organization as well as the counselling and overall treatment with IMed infusions offered to patients in a standardized treatment setting. Furthermore to ensure a high level of safety patients need to receive individualized information, and drug interactions and contraindications need to be excluded - which is not usually the case with nutritional supplements. Especially, since treatment protocols for breast cancer are getting more complex, with novel treatment options like CDK4-inhibitors, PARP-inhibitors or immunotherapies advancing to be included into routine clinical practice [23], counselling on safety of integrative medicine including multinutrient therapies is important. Vitamin infusions are generally well tolerated and safe for administration together with chemotherapy $[15,16]$. Although chemotherapy did not influence the pharmacokinetic profile of vitamin C in plasma, cytotoxic effects of chemotherapy were increased synergistically in tumor cells in preclinical studies $[16,24]$. Concomitant administration of vitamin $C$ and chemotherapy was not found to increase toxicity in clinical trials $[14,16,25]$. This is also in accordance with the small range of side effects reported by the patients in this study. Overall these side effects were only mild.

It has also been reported in the literature that chemotherapy patients in particular try to reduce their side effects using integrative medicine $[21,22]$. Therefore we evaluated if patients could improve side effects of conventional therapy and self-reported quality of life. Especially, in fatigue/tiredness and exhaustion patients reported to benefit. Also the majority of patients reported satisfaction regarding the improvement of quality of life. This is similar to observations from clinical trials investigating vitamin C infusions in patients with cancer disease $[15,16]$. As health-related quality of life is significantly reduced in patients with breast cancer, regardless if they are in adjuvant or metastatic treatment situation, improving or maintaining a high level of quality of life must be a continual treatment goal [26].

Few data are available concerning the use and influence of multinutrient infusions in gynecological cancer patients. Vitamin $C$ has been studied best so far; few data are available on the intravenous administration of other micronutrients in cancer patients. Vitamin C in particular has been proposed for cancer therapy, due to its antioxidant and pro-oxidant effects, as well as its antiproliferative activity in vitro [27]. A few case reports and observational studies have suggested a benefit of high-dose vitamin C infusions, but there is still a lack of clinical evidence for a cytotoxic effect. Neither improvements in time to progression nor any increase in the overall survival time have been adequately established in clinical trials when vitamin $\mathrm{C}$ was administered concomitantly with chemotherapy [16, 28-30].

A plasma concentration of $>10 \mathrm{mM} / \mathrm{L}$ is necessary in order to reach the potentially effective range [28]. No additional benefits are anticipated with higher plasma concentrations [15, 28]. A vitamin C dose of $1.5 \mathrm{~g} / \mathrm{kg}$ three times a week has been proposed, as this dosage has been established as safe [14, 24, 28].

In a pilot phase I/II clinical trial including 25 patients with ovarian cancer, 13 patients received high-dose vitamin C i.v. twice weekly in addition to conventional treatment with carboplatin and paclitaxel. Side effects of chemotherapy such as neurotoxicity, bone marrow toxicity, infection, hepatobiliary toxicity, renal toxicity, as well as gastrointestinal and dermal symptoms, were reduced in patients treated with vitamin $C[15,31]$. Similar effects have been reported in breast cancer patients [32].

As with vitamin $C$ infusions some therapeutic benefits have been published the IMed immune infusion was developed for the use in the integrative medicine consultancy service. Vitamin $C$ stimulates the immune system and is therefore recommended to patients susceptible to infections, a common side effect in patients receiving chemotherapy [33].

Myers' Cocktail has been proposed in the treatment of various conditions and has been shown to be associated with clinical improvements in patients with fibromyalgia syndrome [34]. A modified version of Myers' Cocktail, the IMed regeneration infusion, was included in the IMed infusion portfolio. As stimulation effects have been reported for this formulation [17], it is recommended for patients with fatigue and lack of motivation. Fatigue is one of the most common side effects of breast cancer therapy reported by patients in an integrative medicine setting [35]. This offers an explanation why the IMed regeneration infusion is the most commonly used infusion by patients in this study.

Two further IMed infusion formulars, the IMed vital infusion and the IMed cell protection infusion, have been developed to provide an integrative treatment option for patients with anxiety or for patients who want to support their cardiac cycle. Both, the wish to reduce anxiety and to promote the basic functions of the body like the cardiac cycle or metabolism are treatment goals commonly stated by cancer patients [2].

The general recommendation for the IMed infusion protocols is an administration of 10 infusions. However, the median number of infusions received by patients was only one to four, depending on the type of infusion. Reasons for this discrepancy are that in some cases therapy with IMed infusions is still ongoing. Moreover, many patients switched between treatments. Further reasons why patients stopped treatment with IMed infusions early could be financial reasons as the infusions are not covered by general health insurances and must be paid by patients out of their own pocket.

The present study has several strengths and limitations. The fact that it addresses a topical and under-researched subject is one strength. The infusion protocols were professionally developed with the hospital pharmacy. The preparation and administration were carried out in standardized conditions and in a standardized setting in order to offer patients the greatest possible quality and safety.

However, the number of patients included was very small. Only 20 patients were included in the follow-up survey. In this survey we included only questionnaires of patients who had received their last IMed infusion less than 4 months prior to the survey or in whom the administration was still ongoing. Hence, we had to 
exclude a large number of questionnaires from the analysis. However, by this approach we could ensure that all evaluated patients could sufficiently remember the IMed infusions, especially in terms of side effects and satisfaction. The analysis should therefore be continued in a larger group of patients. The study was conducted exclusively in the integrative medicine consultancy service, which forms part of a specialized breast cancer center at a university hospital; hence, there was no control group. Although the consultancy service was open to all patients, regardless of where they were receiving cancer treatment, there might still have been some potential bias in relation to the study population. Further limitations are the retrospective study design and the purely descriptive statistics. However, data were acquired using a validated and standardized questionnaire. Direct communication with the patients in the follow-up interviews also ensured that the patients understood all of the questions correctly and answered the questionnaire in full, providing high-quality data.

Of course, due to the small number of cases and the short follow-up period, no conclusions can be drawn regarding the effectiveness of the treatment, particularly with regard to reducing the side effects of cancer and the oncological therapy, as well as improvements in quality of life. However, the patients' satisfaction with the counseling provided, with the organization of the service, with their overall treatment and with the tolerability of the supportive infusions were parameters that could be assessed very well.

\section{Conclusion}

In summary, therapy with multinutrient infusions requires the same standards as those set for drug therapy, both in preparation and administration. Although vitamins are dietary supplements, an appropriate patient history must be taken and detailed provision of patient information must be carried out. For this purpose, standardized processes, as in the context of a specialized integrative medicine consultancy service, are helpful. However, further research is needed in order to better investigate the application of multinutrient infusions and their benefits, effects, and safety.

\section{Acknowledgements}

We are grateful to all patients, to the research personnel involved, and to hospital staff. The contribution of N. Weber to this publication was made in partial fulfillment of the requirements for obtaining the doctoral degree "Dr. med." Parts of the research published here have been used for her doctoral thesis in the Medical Faculty of Friedrich Alexander University of Erlangen-Nuremberg (FAU).

Conflict of Interest

Peter A. Fasching has received honoraria from Pfizer, Novartis, Roche, and Amgen. Carolin C. Hack has received honoraria from Roche. All of the other authors have declared that they have no conflicts of interest.

\section{References}

[1] Consortium of Academic Health Centers for Integrative Medicine (CAHCIM). Academic Consortium for Integrative Medicine \& Health, ed.; 2017. Online: https://www.imconsortium.org/about/about-us.cfm; last access: 16.08.2017

[2] Hack CC, Hüttner NBM, Paepke D et al. Integrative Medizin in der Gynäkologischen Onkologie - Möglichkeiten und Grenzen Teil 1. Senologie Zeitschrift für Mammadiagnostik und -therapie 2014; 11: 217-226

[3] Kalder M, Müller T, Fischer D et al.; Arbeitsgruppe Integrative Medizin (AG IMed) der AGO e.V. Begriffsdefinition, Gründung, Ziele und Perspektiven der AG Integrative Medizin. Geburtsh Frauenheilk 2015; 75: 532536. doi:10.1055/s-0035-1546226

[4] Horneber M, Bueschel G, Dennert G et al. How many cancer patients use complementary and alternative medicine: a systematic review and metaanalysis. Integr Cancer Ther 2012; 11: 187-203

[5] Molassiotis A, Fernadez-Ortega P, Pud D et al. Use of complementary and alternative medicine in cancer patients: a European survey. Ann Oncol 2005; 16: 655-663

[6] Molassiotis A, Scott JA, Kearney $\mathrm{N}$ et al. Complementary and alternative medicine use in breast cancer patients in Europe. Support Care Cancer 2006; 14: 260-267

[7] Molassiotis A, Browall M, Milovics L et al. Complementary and alternative medicine use in patients with gynecological cancers in Europe. Int J Gynecol Cancer 2006; 16 (Suppl. 1): 219-224

[8] Fremd C, Hack CC, Schneeweiss A et al. Use of complementary and integrative medicine among German breast cancer patients: predictors and implications for patient care within the PRAEGNANT study network. Arch Gynecol Obstet 2017; 295: 1239-1245

[9] Hack CC, Fasching PA, Fehm T et al. Interest in Integrative Medicine Among Postmenopausal Hormone Receptor-Positive Breast Cancer Patients in the EvAluate-TM Study. Integr Cancer Ther 2017; 16: 165-175. doi: $10.1177 / 1534735416668575$

[10] Hack CC, Hüttner NB, Fasching PA et al. Development and Validation of a Standardized Questionnaire and Standardized Diary for Use in Integrative Medicine Consultations in Gynecologic Oncology. Geburtsh Frauenheilk 2015; 75: 377-383

[11] Klein E, Beckmann MW, Bader W et al. Gynecologic oncologists' attitudes and practices relating to integrative medicine: results of a nationwide AGO survey. Arch Gynecol Obstet 2017; 296: 295-301

[12] Weijl NI, Hopman GD, Wipkink-Bakker A et al. Cisplatin combination chemotherapy induces a fall in plasma antioxidants of cancer patients. Ann Oncol 1998; 9: 1331-1337

[13] Hack CC, Voiss P, Lange S et al. Local and Systemic Therapies for Breast Cancer Patients: Reducing Short-term Symptoms with the Methods of Integrative Medicine. Geburtsh Frauenheilk 2015; 75: 675-682

[14] Hoffer LJ, Levine M, Assouline $S$ et al. Phase I clinical trial of i.v. ascorbic acid in advanced malignancy. Ann Oncol 2008; 19: 1969-1974

[15] Fritz H, Flower G, Weeks L et al. Intravenous Vitamin C and Cancer: A Systematic Review. Integr Cancer Ther 2014; 13: 280-300

[16] Hoffer LJ, Robitaille L, Zakarian R et al. High-dose intravenous vitamin C combined with cytotoxic chemotherapy in patients with advanced cancer: a phase I-II clinical trial. PLoS One 2015; 10: e0120228

[17] Gaby AR. Intravenous nutrient therapy: the "Myers' cocktail”. Altern Med Rev 2002; 7: 389-403

[18] Lonsdale D, Shamberger RJ, Stahl JP et al. Evaluation of the biochemical effects of administration of intravenous nutrients using erythrocyte ATP/ ADP ratios. Altern Med Rev 1999; 4: 37-44

[19] DiGianni LM, Garber JE, Winer EP. Complementary and alternative medicine use among women with breast cancer. J Clin Oncol 2002; 20: $34 \mathrm{~S}-38 \mathrm{~S}$ 
[20] Jacobson JS, Chetty AP. Complementary and alternative medicine in prostate cancer. Curr Oncol Rep 2001; 3: 448-452

[21] Greenlee H, Neugut Al, Falci L et al. Association Between Complementary and Alternative Medicine Use and Breast Cancer Chemotherapy Initiation: The Breast Cancer Quality of Care (BQUAL) Study. JAMA Oncol 2016; 2: 1170-1176

[22] Sweet E, Dowd F, Zhou M et al. The Use of Complementary and Alternative Medicine Supplements of Potential Concern during Breast Cancer Chemotherapy. Evid Based Complement Alternat Med 2016; 2016 : 4382687

[23] Lux MP, Janni W, Hartkopf AD et al. Update Breast Cancer 2017 - Implementation of Novel Therapies. Geburtsh Frauenheilk 2017; 77: 12811290

[24] Du J, Cullen J], Buettner GR. Ascorbic acid: chemistry, biology and the treatment of cancer. Biochim Biophys Acta 2012; 1826: 443-457

[25] Monti DA, Mitchell E, Bazzan AJ et al. Phase I evaluation of intravenous ascorbic acid in combination with gemcitabine and erlotinib in patients with metastatic pancreatic cancer. PLoS One 2012; 7: e29794

[26] Wallwiener M, Simoes E, Sokolov AN et al. Health-related Quality of Life in Metastatic and Adjuvant Breast Cancer Patients. Geburtsh Frauenheilk 2016; 76: 1065-1073

[27] Gonzalez M], Miranda-Massari JR, Mora EM et al. Orthomolecular oncology review: ascorbic acid and cancer 25 years later. Integr Cancer Ther 2005; 4: 32-44

[28] Cabanillas F. Vitamin C and cancer: what can we conclude-1,609 patients and 33 years later? P R Health Sci J 2010; 29: 215-217
[29] Riordan HD, Casciari J], Gonzalez M] et al. A pilot clinical study of continuous intravenous ascorbate in terminal cancer patients. P R Health Sci J 2005; 24: 269-276

[30] Stephenson CM, Levin RD, Spector T et al. Phase I clinical trial to evaluate the safety, tolerability, and pharmacokinetics of high-dose intravenous ascorbic acid in patients with advanced cancer. Cancer Chemother Pharmacol 2013; 72: 139-146

[31] Ma Y, Chapman J, Levine M et al. High-dose parenteral ascorbate enhanced chemosensitivity of ovarian cancer and reduced toxicity of chemotherapy. Sci Transl Med 2014; 6: 222ra218

[32] Jacobs C, Hutton B, $\mathrm{Ng}$ T et al. Is there a role for oral or intravenous ascorbate (vitamin C) in treating patients with cancer? A systematic review. Oncologist 2015; 20: 210-223

[33] Leitlinienprogramm Onkologie der AWMF, Deutschen Krebsgesellschaft e.V. und Deutschen Krebshilfe e.V.; Arbeitsgemeinschaft der Wissenschaftlichen Medizinischen Fachgesellschaften (AWMF) e.V. Interdisziplinäre S3-Leitlinie für die Früherkennung, Diagnostik, Therapie und Nachsorge des Mammakarzinoms. AWMF Registernummer: 032045OL. 4.0. 2017. Online: http://www.leitlinienprogramm-onkologie. de/fileadmin/user_upload/LL_Mammakarzinom_Langversion_4.0.pdf; last access: 01.02.2018

[34] Ali A, Njike VY, Northrup V et al. Intravenous micronutrient therapy (Myers' Cocktail) for fibromyalgia: a placebo-controlled pilot study. J Altern Complement Med 2009; 15: 247-257

[35] Hack CC, Hackl J, Huttner NBM et al. Self-reported Improvement in Side Effects and Quality of Life With Integrative Medicine in Breast Cancer Patients. Integr Cancer Ther 2018; 17: 941-951 